University of Nebraska - Lincoln

DigitalCommons@University of Nebraska - Lincoln

Faculty Papers and Publications in Animal

Science

Animal Science Department

December 2002

Breed comparisons of Angus, Charolais, Hereford, Jersey, Limousin, Simmental, and South Devon for weight, weight adjusted for body condition score, height, and body condition score of cows

Jesus Arango

University of Nebraska-Lincoln, jarango2@unl.edu

L. V. Cundiff

USDA, ARS, Roman L. Hruska U.S. Meat Animal Research Center

L. Dale Van Vleck

University of Nebraska-Lincoln, dvan-vleck1@unl.edu

Follow this and additional works at: https://digitalcommons.unl.edu/animalscifacpub

Part of the Animal Sciences Commons

Arango, Jesus; Cundiff, L. V.; and Van Vleck, L. Dale, "Breed comparisons of Angus, Charolais, Hereford, Jersey, Limousin, Simmental, and South Devon for weight, weight adjusted for body condition score, height, and body condition score of cows" (2002). Faculty Papers and Publications in Animal Science. 226.

https://digitalcommons.unl.edu/animalscifacpub/226

This Article is brought to you for free and open access by the Animal Science Department at DigitalCommons@University of Nebraska - Lincoln. It has been accepted for inclusion in Faculty Papers and Publications in Animal Science by an authorized administrator of DigitalCommons@University of Nebraska - Lincoln. 


\title{
Breed comparisons of Angus, Charolais, Hereford, Jersey, Limousin, Simmental, and South Devon for weight, weight adjusted for body condition score, height, and body condition score of cows ${ }^{1,2}$
}

\author{
J. A. Arango*3, L. V. Cundiff $\dagger$, and L. D. Van Vleck $\dagger \star^{4}$ \\ *Department of Animal Science, University of Nebraska, Lincoln 68583-0908; and USDA, ARS, Roman L. \\ Hruska U.S. Meat Animal Research Center, †Clay Center, NE 68933 and $\ddagger$ Lincoln, NE 68583-0908
}

\begin{abstract}
Breed means and differences for weight $(\mathrm{CW}, \mathrm{n}=19,851)$, height $(\mathrm{CH}, \mathrm{n}=14,553)$, and condition scores $(\mathrm{CS}, \mathrm{n}=19,536)$ recorded in four seasons per year were evaluated for 881 cows ranging from 2 to 7 yr of age from Cycle I of the Germplasm Evaluation Program at the U.S. Meat Animal Research Center. Cows were straightbred Herefords and Angus and topcrosses from mating of Hereford, Angus, South Devon, Jersey, Simmental, Limousin, and Charolais sires to Hereford and Angus dams. The model included cow age, season of measurement, and their interactions, with year of birth, pregnancy-lactation (PL) code, and breed group as fixed effects for CW and CS. Analyses of weight adjusted for condition score included CS as covariate. Model for CH excluded PL. Random effects were additive genetic and permanent environmental effects. Data were analyzed by REML. Differences due to breeds of sire were significant for all traits. Differences were gen-
\end{abstract}

erally maintained across ages, with few interchanges in ranking through maturity. Rankings were in the following order: Jersey (lightest and shortest), Hereford-Angus (and reciprocal), Limousin, South Devon, Simmental, and Charolais (heaviest and tallest). The only exception was that Limousin-sired cows were heavier than South Devon-sired cows after 5 yr of age. Cows sired by breeds of British origin tended to be lighter than breeds of continental European origin. Adjustment for condition score changed estimates of breed differences. Rankings of breed groups, however, were generally the same for actual weight and weight adjusted for condition score. Results indicated that the part of the differences in weight due to differences in condition were of small magnitude. Differences tended to increase when adjusted for condition score, especially in contrasts of continental vs British breeds. Differences among breed groups for height followed differences for weight closely.

Key Words: Beef Cattle, Breed, Growth, Maturity

(C)2002 American Society of Animal Science. All rights reserved.

J. Anim. Sci. 2002. 80:3123-3132

\section{Introduction}

Beef production is characterized by many breeds representing a wide range of biological types for economic traits. Effective utilization of breed differences depends on complete characterization of straightbred and diverse crosses for components of performance. Diverse breeds are required to exploit heterosis and complementarity through crossbreeding and to match genetic po-

\footnotetext{
${ }^{1}$ In memory of Dr. Claudia Gadini.

${ }^{2}$ Published as paper no. 13598, Journal Ser., Nebraska Agric. Res. Div., Univ. of Nebraska, Lincoln 68583-0908.

${ }^{3}$ Current address: Facultad de Ciencias Veterinarias, Universidad Central de Venezuela, Apartado. 4563, Maracay 2101, Aragua, Venezuela.

${ }^{4}$ Correspondence: A218 Animal Sciences (phone: 402-472-6010; fax: 402-472-6362; E-mail: dvan-vleck1@unl.edu).

Received January 4, 2002.

Accepted July 26, 2002.
}

tential with diverse markets, feed resources, and climates (Cundiff et al., 1993). The objective of testing certain breeds of sire in topcrosses is usually to determine the potential benefit of using exotic breeds for crossing with indigenous or local breeds (Dickerson, 1993). The Germplasm Evaluation program (GPE) at the U.S. Meat Animal Research Center (MARC) was designed to evaluate breeds of sires for topcrossing that differ in genetic potential for diverse economic traits, such as growth and mature size, milk production, lean to fat ratio, and carcass characteristics. This paper reports estimates of breed differences for cow weights, weights adjusted for condition score, heights, and body condition scores of Cycle I cows of the GPE program. Previous reports from MARC have presented ordinary least squares means and breed differences for heifers of Cycle I (Laster et al., 1976). Pooled results have been summarized using partial data from the first three cycles of the GPE Program (Cundiff et al., 1986; 1988; Jenkins et al., 1991; Setshwaelo et al., 1990) or from 
Table 1. Number of sires and cows by breed of sire for Cycle I (Phase 2)

\begin{tabular}{lcc}
\hline \hline Breed of sire & Sires & Cows \\
\hline Hereford & 31 & 121 \\
Angus & 33 & 123 \\
Jersey & 32 & 106 \\
South Devon & 27 & 109 \\
Simmental & 27 & 151 \\
Limousin & 20 & 148 \\
Charolais & 26 & 123 \\
Total & 196 & 881 \\
\hline
\end{tabular}

special experiments involving breed groups included in the GPE program (Dearborn et al., 1987). Gregory et al. $(1992 ; 1995)$ have reported least squares means for the same traits for heifers and cows from the Germplasm Utilization (GPU) program at MARC, involving animals of nine pure breeds and three generations of three composite $\left(\mathrm{F}_{1}\right.$ to $\left.\mathrm{F}_{3}\right)$ populations. The objective of this study was to estimate generalized least squares means for weights, heights, and condition scores of cows from Cycle I for all ages that have not previously been published.

\section{Materials and Methods}

Data included weights, heights, and body condition scores of Angus and Hereford purebred and $F_{1}$ cows produced by mating Angus and Hereford dams to seven breeds of sire. The number of sires and cows mated to each breed of sire are presented in Table 1. The GPE program at MARC was designed to examine breed group differences for major economic traits by comparing the progeny of all breeds of sires with progeny from Hereford-Angus crosses. Cycle I began with the 1969 breeding season, with matings by AI of Hereford, Angus, Jersey, South Devon, Limousin, Simmental, and Charolais bulls to Hereford and Angus cows. Details concerning sire sampling were presented by Smith et al. (1976b). Calves were born during a 70-d calving season (March to early May) of 1970, 1971, and 1972. They were allowed to suckle and graze with their mother, and then were creep fed from mid-July or early August until weaning in early October at about $200 \mathrm{~d}$ of age. All male calves were raised, fed, and slaughtered to evaluate growth, feed efficiency, and carcass traits. All females were retained (Phase 2) for evaluation of reproduction, mature weight, height, and other cow traits as well as for maternal performance. Heifers were managed to have their first calf at two years of age. Details of postweaning management were presented by Laster et al. (1976).

All breed groups were managed as contemporaries during their lifetime. Cows were on improved pastures of cool or summer mixtures of grass and fed supplemental grass hay or alfalfa hay (11 to $14 \mathrm{~kg}$ per animal per day) on alternate days during the winter months. Length of breeding season was about $75 \mathrm{~d}$. Pregnancy was diagnosed by palpation 60 to $75 \mathrm{~d}$ after the end of the breeding season. All heifers not diagnosed as pregnant and those failing to conceive in two successive years were culled from the breeding herd. Animals were not removed because of growth criteria. Yearling heifers were weighed at the beginning and end of the mating season and when palpated for pregnancy. Thereafter, cows were weighed, measured for hip height, and scored for body condition four times each year. One measurement was taken each season: 1) mid-May (spring), at the start of the breeding season; 2) early August (summer), at the end of the breeding season; 3) the end of October (fall), at palpation for pregnancy following weaning, and 4) early February (winter), prior to calving. Body condition score was based on a subjective classification scale of nine points, from extremely thin (emaciated) to extremely fat (very obese). Hip heights were first measured in 1974. Each record of a cow was assigned to one of four physiological codes representing a combination of lactation $(1=$ not lactating, 2 = lactating) code and pregnancy ( 1 = not pregnant, $2=$ pregnant $)$ code. Data for the present study included only records of females from 2 to $7 \mathrm{yr}$ of age (the oldest age allowed). Cows born in 1970 were sold after they weaned their calves in the fall of 1978. Cows born in 1971 and 1972 were sold in the fall of 1979.

Statistical analyses were done using single trait animal models with a derivative-free REML algorithm using the MTDFREML computer programs (Boldman et al., 1995), to estimate variance components and to solve mixed model equations. Models included sire breed, dam breed, and their interactions; age (rounded to years), season of measurement, and their interactions; and year of birth and pregnancy-lactation code as fixed effects for cow weight and body condition score. Random effects included the additive genetic and permanent environmental effects of the cow. For cow height, pregnancy-lactation code was excluded from the previous model because of nonsignificance in preliminary analyses. Analyses of weight adjusted for condition score included condition score as a covariate. The models for separate analyses by age (yr) of cow were the same except that ages in days within seasons of measurement were included as extra covariates. Details about models and estimation of variance components were presented by Arango et al. (2002).

Estimates of (co)variances at convergence were used with mixed model equations to obtain solutions for fixed effects and to estimate linear contrasts for breed comparisons. Three sets of contrasts were tested for each trait and age (yr): 1) the difference of the average for cows of each breed of sire from the average of HerefordAngus (HA) reciprocal cows, 2) the difference for Angus and Hereford purebred cows from the average of their reciprocal crosses, and 3) the difference of cows with Angus dams from cows with Hereford dams. More comparisons were made than there were independent degrees of freedom. Therefore, the error rate may be somewhat different from the nominal indicated by the level 
Table 2. Number of cows $(\mathrm{N})$, observations (n), and unadjusted means $( \pm \mathrm{SD})$ by age for weight $(\mathrm{kg})$, hip height $(\mathrm{cm})$, and body condition score (points) of cows

\begin{tabular}{|c|c|c|c|c|c|c|c|c|c|}
\hline & \multicolumn{3}{|c|}{ Weight } & \multicolumn{3}{|c|}{ Height } & \multicolumn{3}{|c|}{ Condition score } \\
\hline & $\mathrm{N}$ & $\mathrm{n}$ & Mean & $\mathrm{N}$ & $\mathrm{n}$ & Mean & $\mathrm{N}$ & $\mathrm{n}$ & Mean \\
\hline \multicolumn{10}{|c|}{ Age, yr } \\
\hline 2 & 881 & 3,441 & $378 \pm 51$ & 280 & 520 & $121 \pm 5.3$ & 881 & 3,131 & $6.0 \pm 1.3$ \\
\hline 3 & 881 & 3,432 & $429 \pm 54$ & 566 & 1,649 & $123 \pm 5.2$ & 881 & 3,429 & $6.0 \pm 1.2$ \\
\hline 4 & 849 & 3,370 & $459 \pm 59$ & 849 & 2,776 & $124 \pm 5.1$ & 849 & 3,369 & $6.2 \pm 1.2$ \\
\hline 5 & 829 & 3,304 & $489 \pm 65$ & 829 & 3,304 & $125 \pm 4.9$ & 829 & 3,304 & $6.0 \pm 1.2$ \\
\hline 6 & 800 & 3,197 & $520 \pm 66$ & 800 & 3,197 & $126 \pm 3.9$ & 800 & 3,197 & $6.2 \pm 1.0$ \\
\hline 7 & 781 & 3,107 & $548 \pm 67$ & 781 & 3,107 & $126 \pm 5.0$ & 781 & 3,106 & $6.5 \pm 1.0$ \\
\hline
\end{tabular}

of probability. However, the experimental objective was to examine breed of sire effects on major economic traits by comparing all breeds of sires with HA crosses and with each other (Cundiff et al., 1986). Tests of significance should be guides of whether the observed values could have occurred by chance. Differences among crossbred cows will be due to differences in additive genetic effects present in the specific two-breed crosses in addition to any difference due to heterosis for a specific cross (e.g., Frahm and Marshall, 1985).

Heights and weights of cows with these breeds of sire may have changed from when Cycle I of the GPE program was initiated. The GPE program is now reevaluating current sires of the Angus, Charolais, Gelbvieh, Limousin, Red Angus, and Simmental breeds for heights, weights, and condition scores. Collection of the mature data will not be complete until 2008, which will help to document changes in those breeds over the span of time covered by the GPE program.

\section{Results and Discussion}

\section{Cow Weights}

Numbers and means by age of cow for all traits are presented in Table 2. Cows continued gaining weight through $7 \mathrm{yr}$ of age. The largest yearly gain was from 2 to $3 \mathrm{yr}$ of age, accounting for $30 \%$ of the total gain. By $4 \mathrm{yr}$ of age, cows had accumulated most (89\%) of their final weight. Unadjusted means for height did not change much across ages, which indicates that height reaches maturity earlier than weight. In fact, cows had attained $96 \%$ of their final height as 3-yr-olds. Unadjusted means for condition score did not change much across ages, which is expected for a trait that reflects fatness, as fatness changes more within ages (due to differences in physiological status) than across ages.

Estimates of means for breed group of cows for weight by age (yr) are presented in Table 3. Cows of all breed groups showed a similar growth pattern. They gained about $30 \%$ of their total weight (at $7 \mathrm{yr}$ ) during the 6yr period studied. Rankings of cows by breed of sire were consistent across ages in the following order: Jersey (lightest), HA (reciprocal), Limousin, South Devon, Simmental, and Charolais (heaviest), except for $\mathrm{F}_{1} \mathrm{Li}$ - mousin cows, which were heavier than $\mathrm{F}_{1}$ South Devon cows after 5 yr of age. Purebred Angus and Hereford cows had similar weights at each age (Angus were slightly heavier at 6 and $7 \mathrm{yr}$ of age), and were lighter at each age than all crossbred cows, except for cows with Jersey sires. Table 4 shows estimates of contrasts between breed groups with standard errors and significance levels. The first set of contrasts represents deviations of each breed of sire group from the average solution for HA reciprocal cross-cows, which was set to zero. Cows with Jersey sires were lighter $(P<0.01)$ than HA by differences that increased with age from $-38 \mathrm{~kg}$ at $2 \mathrm{yr}$ to $-72 \mathrm{~kg}$ at $7 \mathrm{yr}$. Cows with sires of other breeds outweighed HA cows by differences that varied with breed and age of cow. Cows out of Charolais and Simmental sires were heavier $(P<0.01)$ than HA crosses at every age. However, Charolais crosses outweighed HA by differences ( 41 to $64 \mathrm{~kg}$ ) that were approximately twice as great as the differences by which the second heaviest cross (Simmental-sired; 23 to $32 \mathrm{~kg}$ ) exceeded $\mathrm{HA}$ at all ages. Cows with South Devon sires were significantly heavier than HA at all ages, except at $5 \mathrm{yr}$, when the difference was highly significant. These cows then outweighed HA cows by 11 ( 2 -yr-old) to $23 \mathrm{~kg}$ (5yr-old). Weights of cows from Limousin sires were not significantly different from HA $(P>0.05)$ at extreme ages $(2$ and $7 \mathrm{yr})$, but were heavier at $3,4,5(P<0.01)$, and $6 \mathrm{yr}(P<0.05)$ of age, by differences of $21,24,29$, and $19 \mathrm{~kg}$, respectively. The reciprocal HA cows were heavier than the average of the purebred Hereford and Angus cows at each age $(P<0.01)$ by differences that generally increased with age from 18 (2 yr) to 29 (7 yr) $\mathrm{kg}$. Estimates of direct heterosis for cow weight were from 4.2 (at $5 \mathrm{yr}$ ) to $5.7 \%$ (at 6 and $7 \mathrm{yr}$ ). The differences in weight between cows from Hereford and Angus dams were not significant, except at 4 and $6 \mathrm{yr}$ of age $(P<$ 0.05 ), when daughters of Hereford cows were $7 \mathrm{~kg}$ heavier than daughters of Angus cows.

Laster et al. (1976) reported weights of heifers (550 d) from Cycle I. Their ranking of breed groups was similar, but the magnitudes of the differences were less than in the present study, as was expected from weights at an earlier age. The only important differences in the two studies were for heifers with Limousin sires, which had weights that were almost the same $(-1 \mathrm{~kg})$ as those 
Table 3. Estimates of breed group means for weight $(\mathrm{kg})$ of $\mathrm{cows}^{\mathrm{a}}$

\begin{tabular}{lcccccc}
\hline \hline & \multicolumn{5}{c}{ Age of cow, yr } \\
\cline { 2 - 6 } Breed group $^{\text {b }}$ & 2 & 3 & 4 & 5 & 6 & 7 \\
\hline H & 355 & 405 & 430 & 463 & 488 & 510 \\
A & 356 & 402 & 427 & 455 & 492 & 518 \\
H-A & 375 & 425 & 453 & 479 & 514 & 544 \\
A-H & 373 & 421 & 451 & 477 & 511 & 542 \\
Ch-H & 414 & 479 & 514 & 545 & 575 & 603 \\
Ch-A & 415 & 480 & 511 & 538 & 567 & 595 \\
Je-H & 339 & 375 & 402 & 428 & 453 & 471 \\
Je-A & 332 & 367 & 391 & 421 & 448 & 472 \\
Sd-H & 386 & 444 & 474 & 503 & 537 & 571 \\
Sd-A & 383 & 434 & 467 & 499 & 525 & 551 \\
Si-H & 400 & 459 & 490 & 516 & 542 & 567 \\
Si-A & 394 & 447 & 476 & 503 & 533 & 565 \\
Li-H & 383 & 448 & 481 & 513 & 536 & 558 \\
Li-A & 381 & 440 & 471 & 500 & 524 & 547 \\
\hline
\end{tabular}

${ }^{a}$ Means were obtained by adding the unadjusted mean for Hereford-Angus cows (whose solution was constrained to zero in the analysis) to solutions for each breed group.

${ }^{\mathrm{b}} \mathrm{H}=$ Hereford, A = Angus, Ch = Charolais, Je = Jersey, Sd = South Devon, $\mathrm{Si}=$ Simmental, Li = Limousin.

for HA females, and for heifers from Simmental sires that were slightly $\left(5 \mathrm{~kg}\right.$ ) heavier than the $\mathrm{F}_{1}$ females from Charolais sires. Gregory et al. (1992; 1995) reported weights of purebred and crossbred cows from the GPU program. In their analyses, mean weights of purebred cows from 2 to $7+$ yr of age were greater than those in the present study, which ranged from 428 to $579 \mathrm{~kg}$ (Hereford) and 423 to $557 \mathrm{~kg}$ (Angus). Hereford cows were heavier than Angus cows at each age, as was the case in this study, and the differences, ranging from $5(2 \mathrm{yr})$ to $22 \mathrm{~kg}$ ( $7+\mathrm{yr}$ ), were not statistically significant $(P>0.05)$.
In general, a survey of the literature supports what was found in the present study. Cows tend to continue growing until late ages, but at a decreased rate after 4 to $5 \mathrm{yr}$ of age, a time at which many studies set the limit for mature weight (Brown et al., 1956a,b; Morrow et al., 1978; Johnson et al., 1990). Many studies have reported weights of Angus and Hereford cows at different ages. The averages of $9,10,9,9,5$, and 4 reports of weights at $2,3,4,5,6$, and $7 \mathrm{yr}$ of age for Angus cows were 411, 437, 468, 485, 510, and $499 \mathrm{~kg}$ (Brown et al., 1956a,b,c; Brown and Franks, 1964; Smith et al., 1976a; Spelbring et al., 1977; Nadarajah et al., 1984;

Table 4. Contrasts between breed groups $( \pm S E)$ and variance component estimates (VCE) for weight $(\mathrm{kg})$ of cows

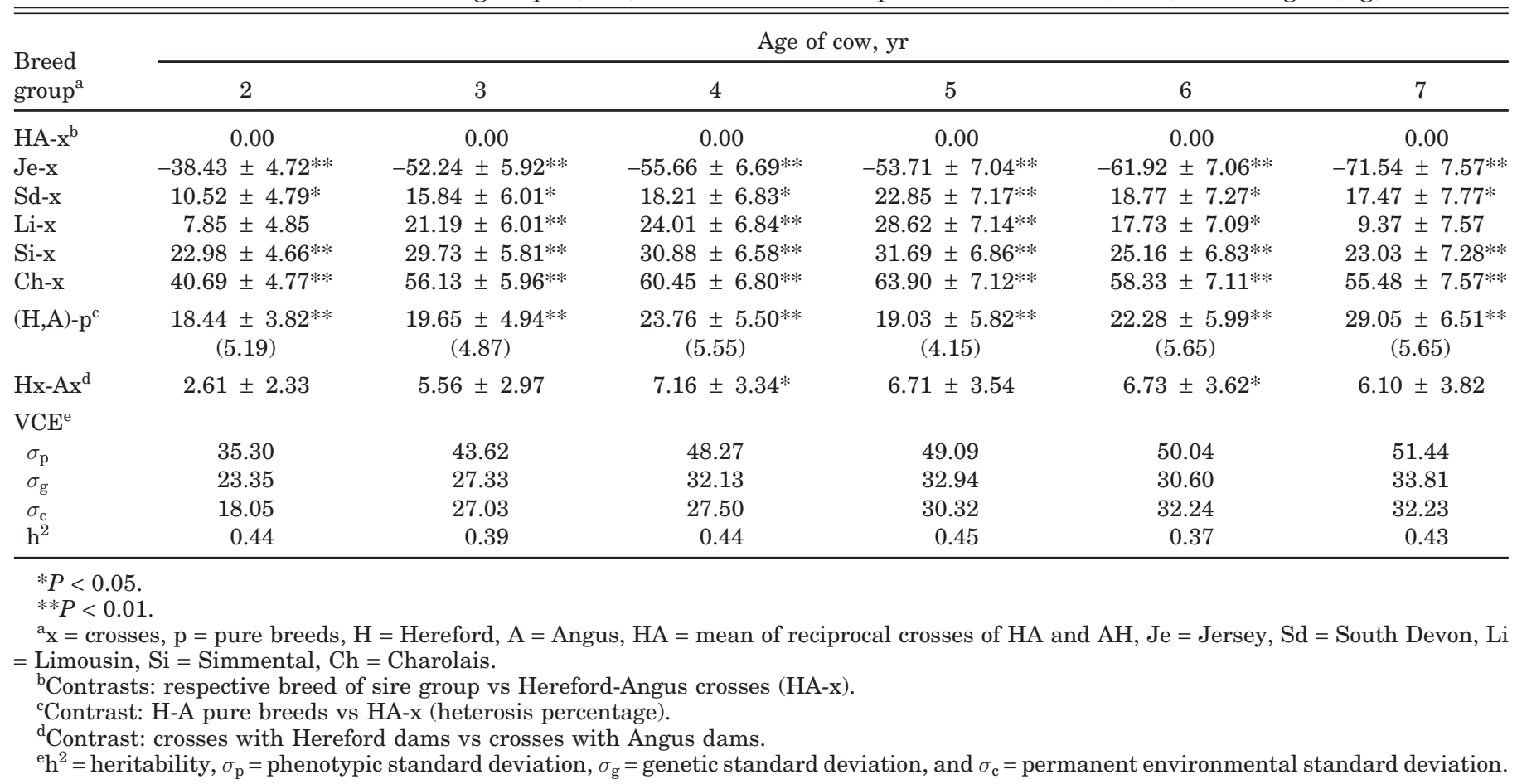


Marlowe and Morrow, 1985; Sacco et al., 1990; Beltran et al., 1992; Northcutt et al., 1992; Archer et al., 1998). The corresponding averages for $5,8,4,6,4$, and 4 reported weights for Hereford cows were 402, 455, 487, 498, 518, and $523 \mathrm{~kg}$ (Brown et al., 1956a,b; Brinks et al., 1962; Brown and Franks, 1964; Butts et al., 1971; Benyshek and Marlowe, 1973; Smith et al., 1976a; Wyatt et al., 1977; Field et al., 1988; Sacco et al., 1990; Meyer, 1995). Averages from previous reports agree with the present study that at $2 \mathrm{yr}$ of age, Angus cows outweighed Hereford cows. At later ages, Hereford cows, however, were heavier. A similar situation was found in studies that reported weights of the two breeds. Brown et al. (1956a,b) found the same weights for Hereford and Angus cows at $2 \mathrm{yr}$ of age $(392 \mathrm{~kg})$, but at later ages, Hereford cows were heavier by differences that increased with age from $2 \mathrm{~kg}$ at $3 \mathrm{yr}$ to $43 \mathrm{~kg}$ at $9 \mathrm{yr}$. Brown and Franks (1964) reported Angus cows were similar in weight to Hereford cows (363 vs $362 \mathrm{~kg}$ ) at $3 \mathrm{yr}$ of age. Smith et al. (1976a) found Hereford cows to be heavier than Angus cows at $31 / 3(38 \mathrm{~kg})$ and 6 to $9(26 \mathrm{~kg})$ yr of age, whereas reciprocal cross HA cows were 22 and $14 \mathrm{~kg}$, or 6.3 and $3.4 \%$ heavier, than the average of the purebreds at the same ages. Sacco et al. (1990) reported Hereford cows to be $6 \mathrm{~kg}$ heavier than Angus cows between 3 and 4 yr of age. Their reciprocal crosses were $5 \mathrm{~kg}$ or $3.6 \%$ heavier than the average of the purebreds.

A sample of $\mathrm{HA}$ and $\mathrm{F}_{1}$ heifers from Charolais, Jersey, and Simmental sires and Angus dams from Cycle I of the GPE program were transferred to Alberta, Canada (Bowden, 1977; 1980). Order of ranking according to breed of sire was the same as in the present study at $2 \mathrm{yr}$ of age under different diets. Differences of the $\mathrm{F}_{1}$ females from Jersey, Simmental, and Charolais bulls from HA were -38, 25, and $53 \mathrm{~kg}$ (Bowden, 1980), similar to the $-38,23$, and $41 \mathrm{~kg}$ found in the present study at $2 \mathrm{yr}$ of age. Nadarajah et al. (1984) reported estimates for Charolais-Angus cows of 445, 485, 498, and $516 \mathrm{~kg}$ from 3 to $6 \mathrm{yr}$ of age that were 47, 58, 68, and $57 \mathrm{~kg}$ greater $(P<0.01)$ than the respective estimates for Angus cows. Frahm and Marshall (1985) compared HA reciprocal crosses with $\mathrm{F}_{1}$ cows with Brown Swiss, Jersey, and Simmental sires and Angus and Hereford dams. Results from that experiment agreed with the present study and with Bowden (1980). On average, cows with Jersey and Simmental sires were -38 and $34 \mathrm{~kg}$ different from the reciprocal HA cows. Corresponding differences at 3 and $4 \mathrm{yr}$ of age were -32 and 31 and -44 and $41 \mathrm{~kg}$, respectively (Frahm and Marshall, 1985). They also reported that cows with Hereford dams were heavier than cows with Angus dams, and that Jersey-cross cows reached maturity for weight at an earlier age relative to other crossbred cows, similar to estimates from the present study. At $3 \mathrm{yr}$ of age, $\mathrm{F}_{1}$ Jersey cows had attained $94.4 \%$ of their mature weight compared to 87.8 and $88.4 \%$ for HA and $\mathrm{F}_{1}$ Simmental cows. Morrison et al. (1989), in a study involving cows with Hereford and Angus dams, and various breeds of sire, reported a weight of $356 \mathrm{~kg}$ for $\mathrm{F}_{1}$ Simmental cows between 2 and $4 \mathrm{yr}$ of age. Cows with Angus and Hereford dams had, on average, the same weight (368 kg). Sacco et al. (1990), from a five-breed diallel experiment in Texas, reported that $\mathrm{F}_{1}$ cows from Jersey sires and Angus and Hereford cows weighed, on average, $385 \mathrm{~kg}$ at $864 \mathrm{~d}$, and were $41 \mathrm{~kg}$ lighter than HA cows.

Table 5 presents estimates of breed group contrasts and standard errors, as well as the significance levels for weight adjusted for condition score. Rankings of crossbred cows were the same as for actual weight. However, breed differences were not the same magnitude. Contrasts and significance levels were somewhat different, which seemed related to milk production and lean to fat ratio of the sire breeds. In general, differences were greater for adjusted weight than for weight, except for cows with Jersey sires (very lean, high milk production), whose differences from HA cows were less for adjusted weight, and for cows with Charolais and $\mathrm{Li}$ mousin (lean, low milk production) sires, for which differences were similar for both weights until $6 \mathrm{yr}$ of age. The estimates of direct heterosis for cow weight adjusted for condition score were slightly less than the estimates for actual weight, ranging from 3.7 ( $5 \mathrm{yr}$ ) to $5.1 \%$ ( $7 \mathrm{yr}$ ). Cows with Hereford dams were 2.5 to $7.2 \mathrm{~kg}$ heavier than cows with Angus dams, but that difference was significant $(P<0.05)$ only at 3,4 , and $6 \mathrm{yr}$ of age, when the superiority of the daughters of Hereford dams was greater than $6 \mathrm{~kg}$. On average, the crossbred cows were heavier $(P<0.01)$ than the purebred (Hereford and Angus) cows at each age by differences that ranged from $27(2 \mathrm{yr})$ to $41(4 \mathrm{yr}) \mathrm{kg}$. Those differences were greater than the differences for actual weights at all ages.

Some studies have presented weights adjusted for condition score at different ages and breed groups. Smith et al. (1976a) found that reciprocal HA cows (6 to $9 \mathrm{yr}$ of age) were $9 \mathrm{~kg}$ or $2 \%$ heavier than the average of the purebreds, a difference that was less than the $26 \mathrm{~kg}(5 \%)$ found in the present study for weight adjusted for condition score. Nadarajah et al. (1984) found Charolais-Angus cows (467 to $527 \mathrm{~kg}$ ) to be 33 to 135 $\mathrm{kg}$ heavier than Angus cows at 3 to $6 \mathrm{yr}$ of age and at maturity ( $7 \mathrm{yr})$. In their study, differences in weights adjusted for condition score of Charolais-Angus cows were always greater than the actual weights, as was the case in the present study.

\section{Cow Height}

Estimates of breed group means for height by age (yr) are presented in Table 6. Cows of all breed groups continued gaining stature through $7 \mathrm{yr}$ of age, but at very low rate at later ages. In fact, almost no increases in height were found after $5 \mathrm{yr}$ of age for any breed group. The increases in stature (4 to $7 \mathrm{~cm}$ ), in the 6 -yr periods reported here, accounted only for 3.1 to $5.4 \%$ of the total stature through $7 \mathrm{yr}$ of age in the different breed groups, indicating that mature height is reached 
Table 5. Contrasts between breed groups $( \pm \mathrm{SE})$ for weight of cows adjusted for body condition score $(\mathrm{kg})$

\begin{tabular}{|c|c|c|c|c|c|c|}
\hline $\begin{array}{l}\text { Breed } \\
\text { group }^{a}\end{array}$ & \multicolumn{6}{|c|}{ Age of cow, yr } \\
\hline$H A-x^{b}$ & 0.00 & 0.00 & 0.00 & 0.00 & 0.00 & 0.00 \\
\hline Je-x & $-34.68 \pm 4.55^{* *}$ & $-36.61 \pm 5.37^{* *}$ & $-33.69 \pm 5.92^{* *}$ & $-40.41 \pm 6.13^{* *}$ & $-48.85 \pm 6.28^{* *}$ & $-57.02 \pm 6.75^{* *}$ \\
\hline $\mathrm{Sd}-\mathrm{x}$ & $13.39 \pm 4.62^{* *}$ & $24.60 \pm 5.44^{* *}$ & $27.30 \pm 6.02^{* *}$ & $27.97 \pm 6.24^{* *}$ & $29.94 \pm 6.46^{* *}$ & $27.51 \pm 6.92^{* *}$ \\
\hline $\mathrm{Li}-\mathrm{x}$ & $11.09 \pm 4.68^{*}$ & $24.85 \pm 5.45^{* *}$ & $25.89 \pm 6.06^{* *}$ & $28.13 \pm 6.26^{* *}$ & $28.24 \pm 6.33^{* *}$ & $21.30 \pm 6.75^{* *}$ \\
\hline Si-x & $26.22 \pm 4.49^{* *}$ & $37.65 \pm 5.27^{* *}$ & $37.37 \pm 5.82^{* *}$ & $36.14 \pm 6.00^{* *}$ & $38.57 \pm 6.10^{* *}$ & $36.71 \pm 6.49 * *$ \\
\hline$(\mathrm{H}, \mathrm{A})-\mathrm{p}^{\mathrm{c}}$ & $\begin{array}{c}17.48 \pm 3.66^{* * *} \\
(4.90)\end{array}$ & $\begin{array}{c}17.91 \pm 4.40^{* * *} \\
(4.40)\end{array}$ & $\begin{array}{c}19.36 \pm 4.73^{* *} \\
(4.45)\end{array}$ & $\begin{array}{c}16.93 \pm 4.92^{* *} \\
(3.66)\end{array}$ & $\begin{array}{c}18.98 \pm 5.27^{* *} \\
(3.84)\end{array}$ & $\begin{array}{c}26.13 \pm 5.74^{* *} \\
(5.05)\end{array}$ \\
\hline$H x-A x^{d}$ & $2.53 \pm 2.03$ & $6.37 \pm 2.42^{*}$ & $6.44 \pm 2.63^{*}$ & $5.24 \pm 2.74$ & $7.20 \pm 2.92^{*}$ & $5.53 \pm 3.09$ \\
\hline \multicolumn{7}{|l|}{$\mathrm{VCE}^{\mathrm{e}}$} \\
\hline$\sigma_{\mathrm{p}}$ & 33.72 & 38.69 & 41.55 & 41.90 & 44.03 & 45.60 \\
\hline$\sigma_{\mathrm{g}}$ & 22.70 & 25.61 & 29.81 & 30.68 & 27.17 & 30.58 \\
\hline
\end{tabular}

earlier than mature weight. Heights at $2 \mathrm{yr}$ of age could be acceptable estimates of mature height for the breed groups considered here. Breed groups tended to cluster in two groups for height. British breeds (Hereford, Angus) and crosses (HA reciprocal crosses and Jersey crosses) tended to have similar heights, which were less than the corresponding heights for crosses with South Devon and continental breeds (Charolais, Limousin, and Simmental). Rankings of breed groups for height shifted across ages, but there was a general tendency for heavier breed groups to be taller. Estimates of contrasts between breed groups and standard errors, as well as significance levels are presented in Table 7. Cows with Jersey sires were not different $(P>0.05)$ from HA cross cows. Cows with sires of continental breeds had similar heights and were taller $(P<0.01)$ than HA at every age. The superiority of the cows with continental sires over the HA cross cows ranged from 5.1 (Limousin at $7 \mathrm{yr}$ ) to $6.9 \mathrm{~cm}$ (Simmental at $2 \mathrm{yr}$ ). Reciprocal HA cows were slightly taller than the average of purebred (Hereford and Angus) cows at each age, but that superiority was significant only when greater than $1 \mathrm{~cm}$ at 4

Table 6. Estimates of breed-group means for cow hip height $(\mathrm{cm})$ of cows ${ }^{\mathrm{a}}$

\begin{tabular}{lcccccc}
\hline \hline & \multicolumn{5}{c}{ Age of cow, yr } \\
\cline { 2 - 7 } $\begin{array}{l}\text { Breed } \\
\text { group }\end{array}$ & 2 & 3 & 4 & 5 & 6 & 7 \\
\hline H & 117 & 119 & 120 & 122 & 122 & 122 \\
A & 116 & 120 & 118 & 120 & 121 & 121 \\
H-A & 117 & 119 & 120 & 122 & 122 & 123 \\
A-H & 117 & 120 & 120 & 122 & 123 & 123 \\
Ch-H & 123 & 125 & 127 & 129 & 130 & 130 \\
Ch-A & 122 & 124 & 126 & 128 & 128 & 129 \\
Je-H & 118 & 120 & 121 & 123 & 123 & 123 \\
Je-A & 118 & 120 & 119 & 121 & 122 & 122 \\
Sd-H & 122 & 125 & 125 & 128 & 128 & 128 \\
Sd-A & 121 & 123 & 125 & 127 & 127 & 127 \\
Si-H & 125 & 126 & 128 & 130 & 130 & 130 \\
Si-A & 123 & 124 & 126 & 127 & 128 & 128 \\
Li-H & 124 & 126 & 127 & 129 & 129 & 129 \\
Li-A & 123 & 124 & 125 & 127 & 127 & 127 \\
\hline
\end{tabular}

${ }^{a}$ Means were obtained by adding the unadjusted mean for H-A cows (whose solution was constrained to zero in the analysis) to solutions for each breed group.

${ }^{\mathrm{b}} \mathrm{H}=$ Hereford, $\mathrm{A}=$ Angus, $\mathrm{Ch}=$ Charolais, Je = Jersey, $\mathrm{Sd}=$ South Devon, $\mathrm{Si}=$ Simmental, Li = Limousin. 
Table 7. Contrasts between breed-groups $( \pm S E)$ and variance component estimates (VCE) for cow hip height $(\mathrm{cm})$ of cows

\begin{tabular}{|c|c|c|c|c|c|c|}
\hline \multirow{2}{*}{$\begin{array}{l}\text { Breed } \\
\text { group }^{a}\end{array}$} & \multicolumn{6}{|c|}{ Age of cow, yr } \\
\hline & 2 & 3 & 4 & 5 & 6 & 7 \\
\hline Je-x & $1.04 \pm 1.16$ & $0.44 \pm 0.72$ & $0.10 \pm 0.56$ & $-0.17 \pm 0.55$ & $-0.30 \pm 0.55$ & $-0.41 \pm 0.56$ \\
\hline Sd-x & $4.86 \pm 0.95^{* *}$ & $4.47 \pm 0.70^{* *}$ & $4.88 \pm 0.58^{* *}$ & $4.95 \pm 0.56^{* *}$ & $4.79 \pm 0.57^{* *}$ & $4.76 \pm 0.58^{* *}$ \\
\hline Li-x & $6.47 \pm 0.85^{* *}$ & $5.21 \pm 0.68^{* *}$ & $5.55 \pm 0.58^{* *}$ & $5.54 \pm 0.56^{* *}$ & $5.31 \pm 0.56^{* *}$ & $5.14 \pm 0.56^{* *}$ \\
\hline Si-x & $6.92 \pm 0.87^{* *}$ & $5.59 \pm 0.66^{* *}$ & $6.59 \pm 0.56^{* *}$ & $6.49 \pm 0.54 * *$ & $6.51 \pm 0.53^{* *}$ & $6.33 \pm 0.54^{* *}$ \\
\hline$(\mathrm{H}, \mathrm{A})-\mathrm{p}^{\mathrm{c}}$ & $\begin{array}{c}0.47 \pm 0.85 \\
(0.41)\end{array}$ & $\begin{array}{c}0.15 \pm 0.59 \\
(0.13)\end{array}$ & $\begin{array}{c}1.24 \pm 0.46^{*} \\
(1.05)\end{array}$ & $\begin{array}{c}0.91 \pm 0.45 \\
(0.75)\end{array}$ & $\begin{array}{c}1.28 \pm 0.45^{* *} \\
(1.06)\end{array}$ & $\begin{array}{c}1.38 \pm 0.47 * * \\
(1.14)\end{array}$ \\
\hline$H x-A x^{d}$ & $0.78 \pm 0.52$ & $1.14 \pm 0.35^{* *}$ & $1.29 \pm 0.28^{* *}$ & $1.25 \pm 0.28^{* *}$ & $1.41 \pm 0.45^{* *}$ & $1.28 \pm 0.28^{* *}$ \\
\hline \multicolumn{7}{|l|}{$\mathrm{VCE}^{\mathrm{e}}$} \\
\hline$\sigma_{\mathrm{p}}$ & 3.87 & 4.05 & 3.97 & 3.92 & 3.78 & 3.75 \\
\hline$\sigma_{\mathrm{g}}$ & 1.74 & 2.74 & 2.76 & 2.63 & 2.56 & 2.55 \\
\hline
\end{tabular}

yr $(P>0.05)$ and after $5 \mathrm{yr}(P<0.01)$. Consequently, heterosis ranged only from 0.1 to $1.1 \%$ across ages. Cows with Hereford dams were taller than cows with Angus dams by differences that were significant $(P<$ 0.01 ) when the difference exceeded $1 \mathrm{~cm}$ after $2 \mathrm{yr}$ of age.

Gregory et al. $(1992 ; 1995)$ reported heights of purebred and composite cows of 2 to $7+$ yr of age from the GPU project at MARC. Hereford cows were 1 to $2 \mathrm{~cm}$ taller than Angus cows as in the present study, but the means for height were greater in their study, ranging from 124 to $129 \mathrm{~cm}$ for Hereford, and from 123 to 127 $\mathrm{cm}$ for Angus.

Results from the literature, in general, agree with the present study that cows tend to approach mature stature earlier than mature weight. In general, cows of different breed groups reached a plateau for height after 3 or $4 \mathrm{yr}$ of age, as in the present study. Brown et al. $(1956 a, b)$ found that measures influenced by soft tissue (muscle and fat) are more variable and attain maturity at later ages than those determined primarily by skeletal structures. In fact, hip height was the earliest maturing measure of size in Hereford and Angus cows in their study, in which cows of both breeds attained about 96 and $98 \%$ of their mature height by 2 and $3 \mathrm{yr}$ of age. On average, heights agreed well with the present study, with Hereford cows being 2 to $5 \mathrm{~cm}$ taller than Angus cows at 2 to 5 yr of age (Brown et al., 1956a,b). The averages of 7, 7,6, and 6 reports of height at 2,3,4, and $5 \mathrm{yr}$ of age for Angus cows were 118, 121, 123, and $123 \mathrm{~cm}$ (Brown et al., 1956a,b,c; Brown and Franks, 1964; Sacco et al., 1990; Northcutt et al., 1992; Archer et al., 1998), which, in general, agree well with the present study. For Hereford cows, Brown et al. (1956b) reported heights of 118 to $123 \mathrm{~cm}$ at 2 to $7 \mathrm{yr}$ of age; Brown and Franks (1964) reported $120 \mathrm{~cm}$ at $3 \mathrm{yr}$ and Sacco et al. (1990) reported $122 \mathrm{~cm}$ at $2.4 \mathrm{yr}$ of age. In general, those heights are similar to the heights reported here. In Australia, Polled Hereford cows measured 129, 130, and $130 \mathrm{~cm}$ at $3+, 4+$, and $5+$ yr of age (Meyer, 1995). In a study in Texas, reciprocal HA cows were, on average, $2 \mathrm{~cm}$ taller (123 vs $121 \mathrm{~cm}$ ) than purebreds (Hereford and Angus) between 2 and 3 yr of age, whereas $F_{1}$ cows with Jersey sires had the same stature as HA cows (Sacco et al., 1990). Bowden (1980) reported that cows with Angus dams and Hereford, Charolais, Jersey, and Simmental sires measured $117,122,117$, and $122 \mathrm{~cm}$ at $2 \mathrm{yr}$ of age, similar to the corresponding heights in the present study.

\section{Body Condition Score}

Estimates of breed group means for body condition score by age (yr) are presented in Table 8 . Condition scores were variable across ages and breed groups, with a narrow range of scores from 5.6 to 7.1, except for Jersey crosses, which had scores below 6.0 until 6 yr of age. This exception may be expected for crosses with a dairy breed, which represents a biological type that is leaner and with greater milk production potential than traditional beef breeds. Condition scores increased steadily, however, from 4 yr of age for Jersey crosses; from $5 \mathrm{yr}$ of age for Angus and Hereford and for HA, South Devon, and Simmental crosses; and from 6 yr of age for Limousin and Charolais crosses. This pattern 
Table 8. Estimates of breed group means for body condition score (points) of cows ${ }^{\mathrm{a}}$

\begin{tabular}{lcccccc}
\hline \hline & \multicolumn{5}{c}{ Age of cow, yr } \\
\cline { 2 - 6 } Breed group $^{\mathrm{b}}$ & 2 & 3 & 4 & 5 & 6 & 7 \\
\hline H & 6.18 & 6.12 & 6.09 & 6.25 & 6.34 & 6.70 \\
A & 6.25 & 6.30 & 6.34 & 6.12 & 6.60 & 7.02 \\
H-A & 6.54 & 6.51 & 6.59 & 6.45 & 6.72 & 7.09 \\
A-H & 6.29 & 6.18 & 6.38 & 6.29 & 6.57 & 6.98 \\
Ch-H & 6.40 & 6.20 & 6.57 & 6.44 & 6.22 & 6.67 \\
Ch-A & 6.32 & 6.42 & 6.66 & 6.31 & 6.16 & 6.54 \\
Je-H & 5.41 & 5.26 & 5.28 & 5.48 & 5.95 & 6.12 \\
Je-A & 5.50 & 5.04 & 5.05 & 5.42 & 5.97 & 6.30 \\
Sd-H & 5.79 & 5.75 & 6.01 & 5.89 & 6.04 & 6.58 \\
Sd-A & 5.84 & 5.63 & 5.87 & 5.91 & 6.10 & 6.33 \\
Si-H & 5.90 & 5.68 & 6.03 & 5.90 & 5.83 & 6.11 \\
Si-A & 5.75 & 5.80 & 6.11 & 5.91 & 6.08 & 6.39 \\
Li-H & 6.00 & 6.16 & 6.49 & 6.23 & 6.15 & 6.34 \\
Li-A & 5.88 & 6.05 & 6.25 & 6.18 & 6.13 & 6.37 \\
\hline
\end{tabular}

${ }^{\mathrm{a}}$ Means were obtained by adding the unadjusted mean for H-A cows (whose solution was constrained to zero in the analysis) to solutions for each breed-group.

${ }^{\mathrm{b}} \mathrm{H}=$ Hereford, A = Angus, $\mathrm{Ch}=$ Charolais, Je = Jersey, $\mathrm{Sd}=$ South Devon, $\mathrm{Si}=$ Simmental, Li = Limousin.

might indicate a relationship between fatness, size, and maturation rate. Smaller and lighter breeds (such as Jersey) tend to mature earlier and begin accumulating fat at earlier ages than taller and heavier breeds (such as Charolais), which mature at later ages.

Table 9 shows estimates of contrasts between breed groups. Reciprocal HA cross cows were superior for condition score at all ages, except for cows with Charolais sires at $4 \mathrm{yr}$ of age (not significant). Cows with Jersey sires had the lowest condition scores, which were less $(P<0.01)$ than HA crosses at each age. South Devonand Simmental-sired cows had similar condition scores and differed $(P<0.01)$ from HA for all ages. Differences of Limousin and Charolais from HA crosses were less consistent across ages. Differences for Limousin crosses were significant $(P<0.01)$ only at 4,6 , and $7 \mathrm{yr}$ of age, whereas Charolais crosses differed significantly from HA $(P<0.01)$ only at 6 and $7 \mathrm{yr}$ of age. The reciprocal HA crosses had slightly greater condition scores than the average of the purebreds (Hereford, Angus), but the difference was significant $(P<0.01)$ only at $4 \mathrm{yr}$ of age. Differences in condition score between cows with Hereford and Angus dams were not significant at any age. On average, crossbred cows had higher condition

Table 9. Contrasts between breed-groups $( \pm S E)$ and variance component estimates (VCE) for body condition score (points) of cows

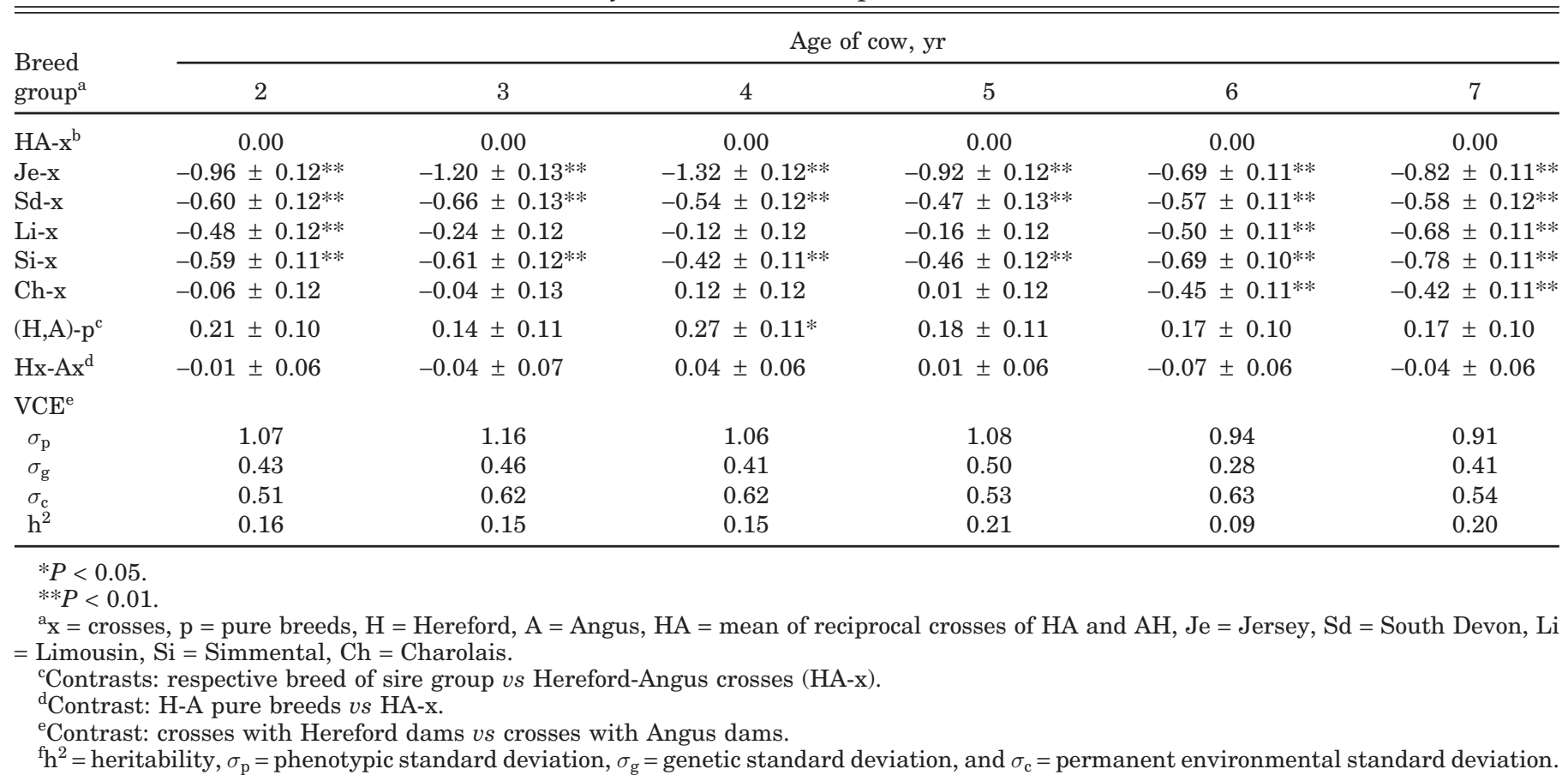


scores than purebred (Hereford and Angus) cows, but the difference was significant $(P<0.01)$ only at 2,3 , and $7 \mathrm{yr}$ of age (Table 9).

Previous reports from MARC included condition scores of purebred and crossbred (composite populations) cows (Gregory et al., 1992; 1995) from 2 to 7+ yr of age. Condition scores tended to increase with age of the cow (as in this study), ranging from 6.0 to 7.0 and from 5.6 to 6.4 points for Hereford and Angus cows, respectively. In contrast to the present study, condition scores were slightly greater for Hereford cows than for Angus cows.

Many studies have reported condition scores of purebred and crossbred cows at different ages, but there has not been a standard way to measure condition in the literature, which makes summarization difficult. Condition has been evaluated by subjective scoring systems with different numeric scales from 0 to 17 (assigned visually or by palpation), by weight:height ratio, and by ultrasound techniques to measure subcutaneous fat. In general, reports from the literature agree with the present study; condition scores tend to increase with age, and Angus and Hereford cows tend to exhibit greater condition scores than crossbred cows with other breeds of sire. Brown et al. (1956c) reported "conformation scores" from Angus cows ( $6=$ medium to $17=$ fancy) measured by a committee (two or more persons). Scores averaged 11.3 (good) and 11.9 (choice) at 2 yr of age (in Maryland) and at maturity (in Tennessee). Spelbring et al. (1977) reported condition scores of 10.6, 10.8, and 10.7 (5 to 15 scale) at 3,4 , and 5 yr of age in a diallel experiment with Milking Shorthorns, in which Angus cows had the greatest condition scores. Nadarajah et al. (1984) reported scores of 2.9, 3.1, 3.5, 3.4, and 3.4 ( 1 to 5 scale) at 32, 44, 56, 68, and 84 mo of age in Angus cows, which were slightly greater than corresponding scores of Charolais-Angus cows (2.7, 3.2, 2.9, 3.1, and 3.1 points) at each age, except at $4 \mathrm{yr}$ of age. Marlowe and Morrow (1985) reported condition scores of 2.6, 2.6, 2.7, 2.8 2.7, and 2.7 (1 to 5 scale) for 2- to 7-yr-old Angus cows in Virginia, in a study that also found condition score to be the most important source of variation for cow weight. Condition scores of Hereford cows for $5 \mathrm{yr}-$ old cows in Montana and Florida have been reported to be 6.7 and 6.1 ( 1 to 9 scale), respectively, in a study of location by origin interaction in which origin was found not to be important (Butts et al., 1971). Benyshek and Marlowe (1973) reported a score of 3.1 (1 to 5 scale) for 7-yr-old cows. Wyatt et al. (1977) reported on an experiment including Hereford, Holstein, and Hereford-Holstein cows under range conditions and a moderate level of supplementation. On average (two measurements during fall and one in spring), Hereford cows had the greatest condition score of 6.0 points ( 1 to 9 scale) at 4 to $5 \mathrm{yr}$ of age. Bowden (1980) evaluated condition by the ratio of weight to height and by ultrasound measurement of backfat thickness in $F_{1}$ cows with Angus dams at $2 \mathrm{yr}$ of age. The HA cows had the greatest fat thickness (7.2), followed closely by Charo-
lais-Angus (7.0), whereas crosses from breeds of sire with greater milk potential had the smallest scores (Simmental-Angus [5.9] and Jersey-Angus [5.6]). The scores are similar to the corresponding condition scores in the present study of $6.5,6.3,5.8$, and 5.5 points.

\section{Implications}

Cows sired by sires of seven breeds representing diverse biological types were significantly different for weight, height, and condition score. Those estimates can be used to match breeding systems with environmental, managerial and market requirements to optimize beef production under conditions similar to those from this experiment. Cow weight reflects differences in size associated not only with skeletal size and lean growth, but also with fatness, which is associated indirectly and negatively with milk production. Adjustment for condition score caused some differences in estimates of breed differences for weight. Ranking of breed groups was generally the same for actual weight and for weight adjusted for condition score, although those results might indicate that a portion of the differences in weight was due to differences in condition, but that those differences were moderate to small. Differences among breed groups for height followed closely differences for weight.

\section{Literature Cited}

Arango, J. A., L. V. Cundiff, and L. D. Van Vleck. 2002. Genetic parameters for weight, weight adjusted for body condition score, height, and body condition score in beef cows. J. Anim. Sci. 80:3112-3122.

Archer, J. A., R. M. Herd, P. F. Arthur, and P. F. Parnell. 1998. Correlated responses in rate of maturation and mature size of cows and steers to divergent selection for yearling growth rate in Angus cattle. Livest. Prod. Sci. 54:183-192.

Beltran, J. J., W. T. Butts, Jr., T. A. Olson, and M. Koger. 1992. Growth patterns of two lines of Angus cattle selected using predicted growth parameters. J. Anim. Sci. 70:734-741.

Benyshek, L. L., and T. J. Marlowe. 1973. Estimating heritability of Hereford cow weights. J. Anim. Sci. 36:854-861.

Boldman, K. G., L. A. Kriese, L. D. Van Vleck, C. P. Van Tassell, and S. D. Kachman. 1995. A Manual for Use of MTDFREML. A Set of Programs to Obtain Estimates of Variances and Covariances [DRAFT]. USDA-ARS, Washington, DC.

Bowden, D. M. 1977. Growth, reproductive performance, and feed utilization of $\mathrm{F}_{1}$ crossbred beef heifers calving as 2-year-olds. J. Anim. Sci. 44:872-882.

Bowden, D. M. 1980. Feed utilization for calf production in the first lactation by 2-yr-old $\mathrm{F}_{1}$ crossbred cows. J. Anim. Sci. 51:304-315.

Brinks, J. S., R. T. Clark, N. M. Kieffer, and J. R. Quesenberry. 1962. Mature weight in Hereford range cows heritability, repeatability, and relationship to calf performance. J. Anim. Sci. 21:501-504.

Brown, C. J., and L. Franks. 1964. Factors affecting size of young beef cows. J. Anim. Sci. 23:665-668.

Brown, C. J., M. L. Ray, W. Gifford, and R. S. Honea. 1956a. Growth and development of Hereford cattle. Ark. Agric. Exp. Stn. Bull. 570, Fayetteville.

Brown, C. J., M. L. Ray, W. Gifford, and R. S. Honea. 1956b. Growth and development of Aberdeen-Angus cattle. Ark. Agric. Exp. Stn. Bull. 571, Fayetteville. 
Brown, C. J., E. J. Warwick, H. J. Smith, W. W. Green, and H. A. Stewart. 1956c. Relationship between conformation score and live measurements of beef cattle. J. Anim. Sci. 15:911-921.

Butts, W. T., M. Koger, O. F. Panish, W. C. Burns, and E. J. Warwick. 1971. Performance of two lines of Hereford cattle in two environments. J. Anim. Sci. 33:923-932.

Cundiff, L. V., K. E. Gregory, R. M. Koch, and G. E. Dickerson. 1986. Genetic diversity among cattle breeds and its use to increase beef production in a temperate environment. Proc. 3rd World Cong. Genet. Appl. Livest. Prod., Lincoln, NE. IX:271-282.

Cundiff, L. V., K. E. Gregory, and R. M. Koch. 1988. Productivity of large sized cattle breeds in beef cow herds in the temperate zones of northern America. Proc. 3rd World Cong. on Sheep and Beef Cattle Breeding, Paris, France. 2:3-23.

Cundiff, L. V., F. Szabo, K. E. Gregory, R. M. Koch, M. E. Dikeman, and J. D. Crouse. 1993. Breed comparisons in the germplasm evaluation program at MARC. In Proc. Beef Improvement Fed. 25th Anniv. Conf., Asheville, NC. Available at: http://pc200.animsci.okstate.edu/BREEDS/RESEARCH/marccomp.htm. Accessed Oct. 2, 1999.

Dearborn, D. D., K. E. Gregory, L. V. Cundiff, and R. M. Koch. 1987. Heterosis and breed maternal and transmitted effects in beef cattle. V. Weight, height and condition score of females. J. Anim. Sci. 64:706-713.

Dickerson, G. E. 1993.Evaluation of Breeds and Crosses of Domestic Animals. FAO Animal Production and Health Paper No. 108. Rome, Italy.

Field, T. G., J. S. Brinks, R. E. Taylor, and J. D. Tatum. 1988. Estimation of genetic parameters for mature weight in Hereford females. Proc. W. Sect. Am. Soc. Anim. Sci. 39:30-32.

Frahm, R. R., and D. M. Marshall. 1985. Comparisons among twobreed cross cow groups. I. Cow productivity and calf performance to weaning. J. Anim. Sci. 61:844-855.

Gregory, K. E., L. V. Cundiff, and R. M. Koch. 1992. Breed effects and heterosis in advanced generations of composite populations on actual weight, adjusted weight, hip height, and condition score of beef cows. J. Anim. Sci. 70:1742-1754.

Gregory, K. E., L. V. Cundiff, and R. M. Koch. 1995. Genetic and phenotypic (co)variances for production traits of female populations of purebred and composite beef cattle. J. Anim. Sci. 73:2235-2242.

Jenkins, T. G., M. Kaps, L. V. Cundiff, and C. L. Ferrell. 1991. Evaluation of between and within-breed variation in measures of weight-age relationships. J. Anim. Sci. 69:3118-3128.
Johnson, Z. B., C. J. Brown, and A. H. Brown, Jr. 1990. Evaluation of growth patterns of beef cattle. Ark. Agric. Exp. Stn. Bull. 923.

Laster, D. B., G. M. Smith, and K. E. Gregory. 1976. Characterization of biological types of cattle: IV. Postweaning growth and puberty of heifers. J. Anim. Sci. 43:63-70.

Marlowe, T. J., and G. A. Morrow. 1985. Heritabilities and phenotypic, genetic and environmental correlations for weight, grade and condition of Angus cows. J. Anim. Sci. 60:82-88.

Meyer, K. 1995. Estimates of genetic parameters for mature weight of Australian beef cows and its relationship to early growth and skeletal measures, Livest. Prod. Sci. 44:125-137.

Morrison, D. G., P. E. Humes, and K. L. Koonce. 1989. Comparison of Brahman and continental European crossbred cows for calving ease in a subtropical environment. J. Anim. Sci. 67:1722-1731.

Morrow, R. E., J. B. McLaren, and W. T. Butts. 1978. Effect of age on estimates of bovine growth-curve parameters. J. Anim. Sci. 47:352-357.

Nadarajah, K., T. J. Marlowe, and D. R. Notter. 1984. Growth patterns of Angus, Charolais, Charolais $\times$ Angus and Holstein $\times$ Charolais cows from birth to maturity. J. Anim. Sci. 59:957-966.

Northcutt, S. L., D. E. Wilson, and R. L. Willham. 1992. Adjusting weight for body condition score in Angus Cows. J. Anim. Sci. 70:1342-1345.

Sacco, R. E., J. F. Baker, T. C. Cartwright, C. R. Long, and J. O. Sanders. 1990. Measurements at calving for straightbred and crossbred cows of diverse types. J. Anim. Sci. 68:3103-3108.

Setshwaelo, L. L., L. V. Cundiff, and G. E. Dickerson. 1990. Breed effects on crossbred cow-calf performance. J. Anim. Sci. 68:1577-1587.

Smith, G. M., H. A. Fitzhugh, Jr., L. V. Cundiff, T. C. Cartwright, and K. E. Gregory. 1976a. Heterosis for maturing weight patterns in Hereford, Angus and Shorthorn cattle. J. Anim. Sci. 43:380-388.

Smith, G. M., D. B. Laster, and K. E. Gregory. 1976b. Characterization of biological types of cattle. I. Dystocia and overweaning growth. J. Anim. Sci. 43:27-31.

Spelbring, M. C., T. G. Martin, and K. J. Dewry. 1977. Maternal productivity of crossbred Angus $\times$ Milking Shorthorn cows. I. Cow and calf weights and scores. J. Anim. Sci. 45:969-975.

Wyatt, R. D., K. S. Lusby, J. V. Whiteman, M. B. Gould, and R. Totusek. 1977. Performance of 4- and 5-year-old Hereford, Hereford $\times$ Holstein and Holstein cows on range and in drylot. J. Anim. Sci. 45:1120-1130. 